\title{
Correction to: Involvement of Nuclear Receptor REV-ERB $\beta$ in Formation of Neurites and Proliferation of Cultured Adult Neural Stem Cells
}

\author{
Koji Shimozaki ${ }^{1}$ (D)
}

Published online: 12 March 2021

(c) Springer Science+Business Media, LLC, part of Springer Nature 2021

\section{Correction to: \\ Cellular and Molecular Neurobiology \\ (2018) 38:1051-1065 \\ https://doi.org/10.1007/s10571-018-0576-7}

The original version of this article unfortunately contained an error in Keywords.

The keyword 'REV-ERB $\beta$ ' should read as 'REV-ERB'.

The original article has been corrected.

Publisher's Note Springer Nature remains neutral with regard to jurisdictional claims in published maps and institutional affiliations.

The original article can be found online at https://doi.org/10.1007/ s10571-018-0576-7.

Koji Shimozaki

shimozak@nagasaki-u.ac.jp

1 Division of Functional Genomics, Life Science Support

Center, Nagasaki University, 1-12-4 Sakamoto,

Nagasaki 852-8523, Japan 